\title{
Dioscin inhibits gastric tumor growth through regulating the expression level of IncRNA HOTAIR
}

Ting Ma ${ }^{1,2}$, Rui-ping Wang ${ }^{2,3,4^{*}}$ and Xi Zou ${ }^{2,3}$

\begin{abstract}
Background: As a member of non-coding RNAs family, long non-coding RNAs' functions in cancer needs to be further investigated. It has been indicated that the functions of Hox transcript antisense intergenic RNA (IncRNA: HOTAIR) include reprogramming chromatin organization and promoting tumor metastasis such as breast and colorectal tumor. The aim of this study is to investigate the functions of Hox in gastric cancer.

Methods: In the present study, the expression level of HOTAIR was determined by quantitative reverse transcription polymerase chain reaction (qRT-PCR), 20 gastric cancer tissues and 20 normal tissues was included. All clinical data were analyzed retrospectively. The CCK-8 and colony formation assay was used to identify if the knockdown of HOTAIR have an influence on gastric cancer cell lines.

Results: Compared with normal tissues, higher expression level of HOTAIR was found in gastric cancer tissues. Dioscin inhibits proliferation of the three gastric cancer cell lines and decrease HOTAIR expression.

Conclusions: The expression of HOTAIR is up regulated in gastric cancer and gastric cancer cell lines, dioscin inhibits the proliferation of three gastric cancer cell lines and the anti-tumor effect of dioscin may partly depend on the down regulation of HOTAIR.
\end{abstract}

Keywords: HOTAIR, Gastric cancer, Dioscin, IncRNA

\section{Background}

Gastric cancer is one of the most prevalent and deadly malignancies worldwide, with an estimated more than 950,000 new cases every year and 720,000 deaths reported in $2012[1,2]$. With the advances in understanding of the ideology of the disease and therapeutic options, the 5-year mortality rate has only been slightly reduced over the last few decades. There is still a pressing need to identify new prognostic biomarkers and therapeutic targets for this disease [3].

As reviewed by Ling et al. [4] traditional Chinese medicine (TCM) can play a vital role in cancer prevention and treatment. The anticancer mechanisms of which involves inducing apoptosis, anti-proliferation, preventing tumor invasion and metastasis, and reducing

\footnotetext{
* Correspondence: rping_wang@126.com

${ }^{2}$ Nanjing University of Chinese Medicine, Nanjing, People's Republic of China

${ }^{3}$ Jiangsu Province Hospital of TCM, Nanjing, People's Republic of China

Full list of author information is available at the end of the article
}

resistance to chemotherapy [5]. More than coadministrate with other drugs to reduce side effects, TCM-derived drugs may also serve as gene therapy vehicles, therapeutic genes and synergistic therapeutic treatments $[6,7]$.

\section{An important class of non coding RNAs are the IncRNAs or long non coding RNAs}

The functions of these RNAs involving vary aspects of genetics $[8,9]$. Until HOTAIR was discovered, it is widely believed that lncRNAs mainly function in cis. Recent studies have demonstrated that lncRNAs are involved in the development of different types of cancer $[10,11]$, for example, metastasis associated lung adenocarcinoma transcript 1 (MALAT-1) in non small cell lung cancer and HOTAIR in breast cancer and colorectal cancer [12-14]. The expression level of genes related to cancer progression was regulated by HOTAIR via interacting with PCR2 complex [9]. However, the 
significance of HOTAIR expression in gastric cancer tissues from clinic has not been fully studied. In the present study, the expression level of HOTAIR in gastric cancer and adjacent normal tissues was detected.

Dioscin is an active ingredient identified in edible medicinal plants such as Dioscorea nipponica Makino and Dioscorea zingiberensis Wright [15]. It has been demonstrated that dioscin has anti-tumor [16] and anti-fungal activities. It has been known that Dioscin induce apoptosis and cell cycle arrest in gastric cancer cells [17]. Dioscin-induced apoptosis is mediated by multiple genes or proteins including caspase-9, caspase-3 and antiapoptotic Bcl-2 protein $[18,19]$. Dioscin could also induce apoptosis through elevating oxidative stress by downregulating peroxiredoxins, promoting ROS accumulation, inducing DNA damage, and activating mitochondrial signal pathways $[20,21]$. However, the anticancer mechanisms of dioscin in human gastric cancer cells have not been delineated. The purpose of this study is to investigate the anticancer effects and molecular targets of dioscin on human gastric cancer cell lines including SGC-7901, MGC-803, and HGC-27. Our results show that the anticancer activities of dioscin against gastric cancer cells may partly depend on the down regulation of long non-coding RNA HOTAIR.

\section{Methods}

\section{Ethics, consents and permissions}

The protocol was approved by the Institutional Review Board at the Traditional Chinese Medicine of Changzhou Hospital (Changzhou, Jiangsu, China). An informed consent form was signed by each participant.

\section{Demographics}

All participants were asked to answer 12 items relating to basic demographics: age, race, ethnicity, sex, education, marital, employment and insurance status, likelihood of insurance billing, household income, and self-reported height and weight. The answers were not scored and treated categorically in data analyses.

\section{Gastric cancer tissue and cell culture}

Gastric cancer tissues were obtained from the Traditional Chinese medicine of Changzhou Hospital (Changzhou, Jiangsu, China). All tissues were immersed in RNA fixative after resection (TIANGEN, Beijing, China) and were deposited in $-80{ }^{\circ} \mathrm{C}$ until use. The age range is between 48 and 70 years and the median is 56 years. The gastric cancer cell lines HGC-27, MGC803, and SGC7901 and normal gastric cell line GES-1 were purchased from the Type Culture Collection of the Chinese Academy of Sciences (Shanghai, China). All cell lines were cultured in RPMI1640 medium supplemented with $10 \%$ fetal bovine serum (FBS), $1 \%$ antibiotic-antimycotic solution, and maintained in a humidified incubator with $5 \% \mathrm{CO}_{2}$ at $37{ }^{\circ} \mathrm{C}$

\section{siRNA knockdown assay}

HOTAIR-siRNA was performed as previously described $[22,23]$. A total of $1.5 \times 10^{5} /$ well HGC-27, MGC803, SGC7901 or GES-1 were seeded into 6-well plates and were transfected with HOTAIR siRNAs $24 \mathrm{~h}$ later using RNAiMAX transfection reagents (Invitrogen, Shanghai, China) according to the instructions. The target sequence of HOTAIR siRNA was UUUUCUACCAGGUCGGUAC.

\section{a}

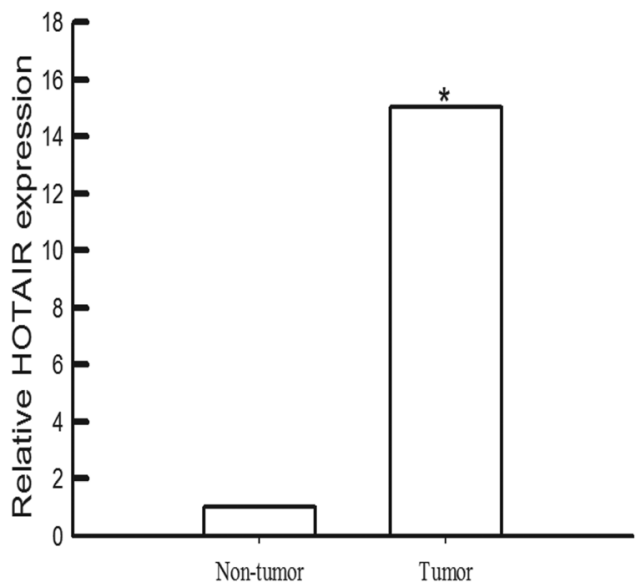

b

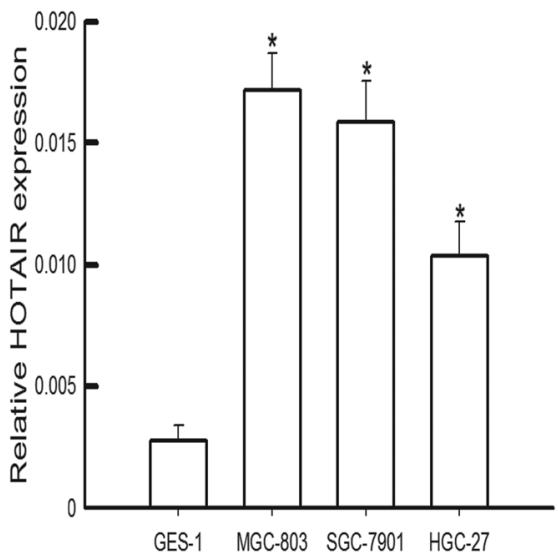

Fig. 1 HOTAIR expression in gastric tumor tissues and gastric cancer cell lines was elevated. a HOTAIR expression was significantly higher in gastric cancer tissues than in non-cancerous tissues. Relative HOTAIR expression was determined using qRT-PCR with GAPDH as the internal control (number of patients was forty, $n=40$ ). $\mathbf{b}$ HOTAIR expression was significantly higher in gastric cancer cell lines were higher than in normal gastric cell line. ${ }^{*} P<0.05$ vs non-tumor tissues 
RNA extraction and quantitative reverse transcription polymerase chain reaction

Total RNA was extracted as previously described [24]. The primers used in this study were HOTAIR: forward:
5' - GGTAGAAAAAGCAACCACGAAGC -3' and reverse: 5' - ACATAAACCTCTGTCTGTGAGTGCC -3'; GAPDH: forward: 5'-AGGACTGGATAAGCAGGGCG -3 ' and reverse: 5'-CTGGAACAGGGAGGAGCAGA -3'.

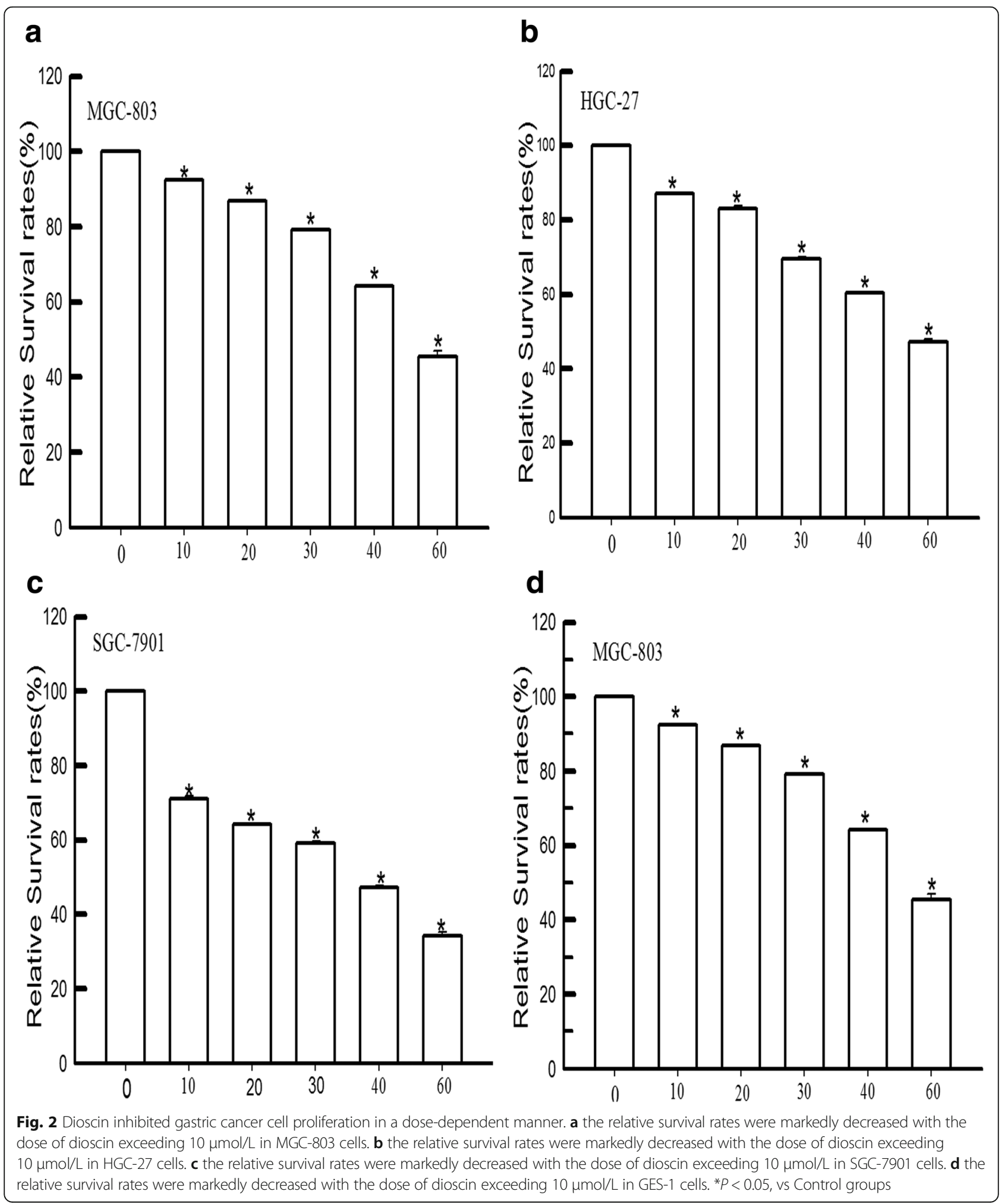




\section{MTT assay}

Cells were plated into 96-well plates at a density of 2000 cells/well. The cells were incubated with different concentration of dioscin (Chengdu Ruifeng Biotechnology Company, Chengdu, China) $(0 \mu \mathrm{mol}, 10 \mu \mathrm{mol}, 20 \mu \mathrm{mol}$, $30 \mu \mathrm{mol}, 40 \mu \mathrm{mol}, 60 \mu \mathrm{mol})$ for $48 \mathrm{~h}$. Then the cells were incubated with 3-(4,5-dimethylthiazol-2-yl)-2,5diphenyltetrazolium bromide (MTT) for $4 \mathrm{~h}$ at $37{ }^{\circ} \mathrm{C}$. The absorbance at $490 \mathrm{~nm}$ was measured.

\section{Colony formation assay}

Cells were seeded into 6-well plates at a density of 500 cells/well. Approximately 10 days later, the cells were fixed with methanol for $10 \mathrm{~min}$ and then stained with $0.5 \%$ crystal violet in $20 \%$ methanol. The number of colonies was counted and representative images were obtained.

\section{Statistical analysis}

All data were shown as the mean. $\pm \mathrm{SD}$, and the experiments were repeated three times. One-way ANOVA was performed, and $P<0.05$ was considered statistically significant.

\section{Results}

HOTAIR expression in clinical tissues, gastric cancer cell lines and noncancerous cell lines

The expression of HOTAIR between gastric cancer tissues and corresponding normal tissues was identified by qRT-PCR. As shown in Fig. 1, HOTAIR expression in gastric cancer tissues was more than 30 -fold of that in normal tissues, suggesting that the expression of HOTAIR was upregulated in gastric cancer. HOTAIR expression in gastric cancer cell lines SGC-7901, MGC803 and HGC-27 were significantly higher than that in noncancerous cancer cell line GES-1 (Fig. 1b).
Effect of dioscin on gastric cancer cell lines and noncancerous cell line

We performed MTT analysis to assess the effect of dioscin on the proliferation of gastric cancer cells. The relative survival rates of gastric cancer cells were markedly decreased with doses of dioscin over $10 \mu \mathrm{mol} / \mathrm{L}(P<0.05)$ (Fig. 2), suggesting that dioscin inhibited gastric cancer and noncancerous cell proliferation in a dose-dependent manner.

\section{HOTAIR knockdown or dioscin decrease cell proliferation in gastric cancer cells}

Based on the results of Figs. 1 and 2, we choose gastric cell line MGC-803 and the concentration of dioscin at $56 \mu \mathrm{mol}$ (Half Maximal Inhibitory Concentration) for further studies. To determine the function roles of HOTAIR and dioscin in gastric cancer, siRNA was used to silence HOTAIR expression, and we also found dioscin down regulated the expression of HOTAIR (Fig. 3a). MGC-803 cells were transfected with HOTAIR siRNA or treated with dioscin for $48 \mathrm{~h}$, then their proliferation was examined using MTT and colony formation assays. As shown in Fig. 4, both HOTAIR siRNA and dioscin could significantly inhibit MGC-803 cells proliferation. The same effect was observed in the colony formation assays.

\section{Discussion}

The expression level of HOTAIR was markedly up regulated in many cancers, which play an important role in multiple biological progress of tumor development [25]. Our data shown the expression level of HOTAIR was drastically higher in gastric cancer tissues and gastric cancer cell lines (MGC-801, SGC-7901 and HGC-27). These data were consisted with previous studies which found the expression of HOTAIR was higher in cancer lesions than in adjacent normal tissues in gastric cancer $[26,27]$.
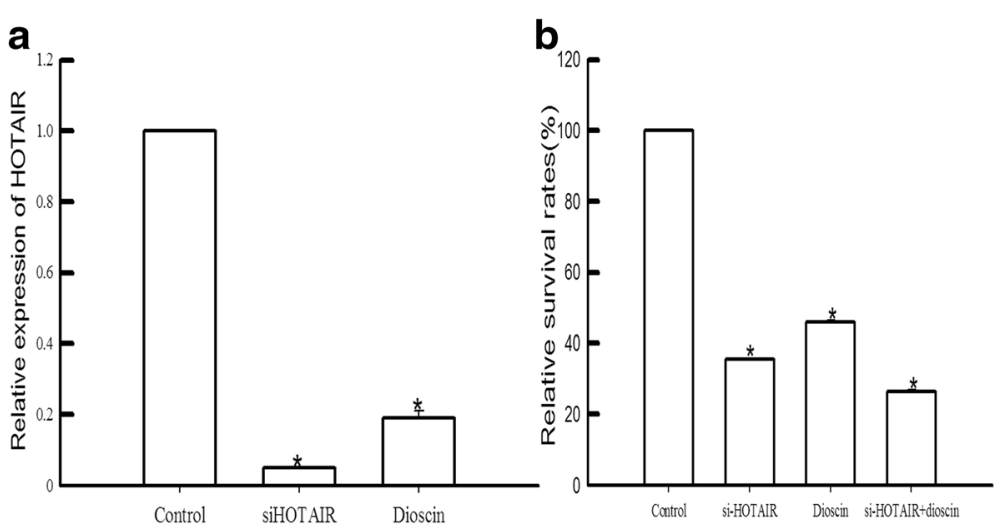

Fig. 3 HOTAIR knockdown or dioscin decreased cell proliferation in gastric cancer cells. a relative expression of HOTAIR in MGC-803 cell transfected with HOTAIR siRNA or treated with dioscin. $\mathbf{b}$ The relative survival rates were markedly decreased with dioscin or HOTAIR siRNA in MGC-803 cells 


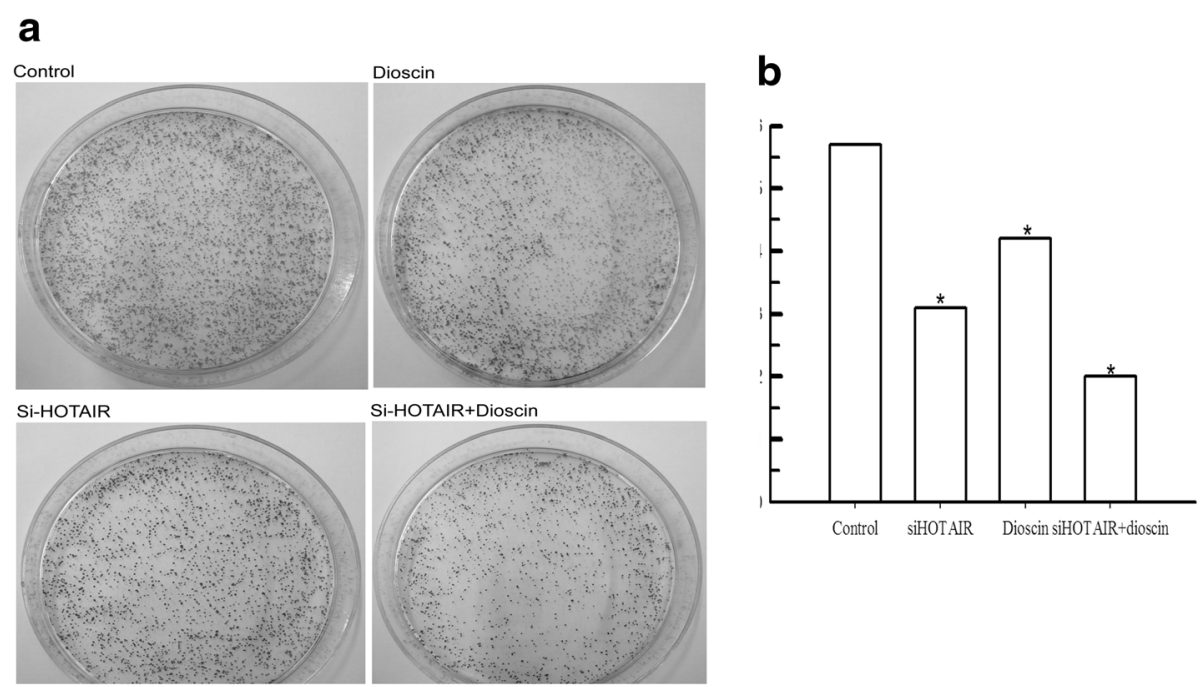

Fig. 4 HOTAIR knockdown or dioscin decreased cell proliferation in gastric cancer cells. Knockdown cells were transfected with si-HOTAIR or treated with dioscin for $24 \mathrm{~h}$ and then plated in $6-\mathrm{cm}$ dishes for 10 days. ${ }^{* P}<0.05$, vs Control groups. a Colony formation assay, the cells were stained with crystal. b Number of colonies

Among the three cell line, the expression level of HOTAIR in MGC-801 was the highest which was used for further MTT and colony formation assay. The data indicated that HOTAIR involved in the proliferation process and colony formation of MGC-801 (shown in Figs. 3B and $4 \mathrm{E})$. It has been shown that HOTAIR expressed highly in high-risk gastrointestinal stoma tumors, and the high expression levels were related to tumor metastasis [28]. Moreover, recent study indicated that HOTAIR function as lymphatic nodes metastasis and survival predictor [27]. Taken together, HOTAIR played an important role in the pathological process of gastric cancer.

It has been known that dioscin inhibits tumor growth through multiple pathways. In colon cancer, dioscin efficiently inhibited VEGFR2 and AKT/MAPK pathways mediated angiogenesis [29]. Dioscin-induced breast cancer cell death via AIF-facilitated caspaseindependent pathway and the down regulation of anti-apoptotic proteins as Bcl-2, cIAP-1, and Mcl-1 [30]. Previous study showed that the activation of the mitrochondrial pathway was associated with antipoliferative effect of dioscin in gastric cancer [31]. Here we showed that dioscin may inhibit the proliferation of gastric cancer through decreasing the expression level of HOTAIR. Further studies are needed to illustrate how dioscin inhibits HOTAIR expression.

\section{Conclusions}

In conclusion, these data showed that the expression of HOTAIR was up regulated in gastric cancer and gastric cancer cell lines. Dioscin inhibited the expression of
HOTAIR and the proliferation rate of gastric cancer cells, indicating that the antitumor effect of dioscin may partly depend on its down regulation of HOTAIR.

\section{Abbreviations}

FBS: Fetal bovine serum; HOTAIR: HOX transcript antisense RNA; IncRNA: long non-coding RNAs; MALAT-1: Metastasis associated lung adenocarcinoma transcript 1; MTT: 3-(4,5-dimethylthiazol-2-yl)-2,5-diphenyltetrazolium bromide; TCM: Traditional Chinese medicine

\section{Funding}

This work was supported by Jiangsu provincial clinical medical project (No.BL2014100), Basic clinical research of national Tradition Chinese Medicine project (No. JDZX2012087) and Jiangsu provincial health project (No.

BJ14013), Changzhou Municipal Health Technology projects (No. WZ201529).

\section{Availability of data and materials}

The data and materials of this article are included within the article.

\section{Authors' contributions}

WRP rafted the original study protocol/manuscript and led study coordination of the manuscript. MT conducted the data analysis and contributed to interpretation of the findings and writing of the manuscript ZX participated in the data analysis. All authors read and approved the final manuscript.

\section{Competing interests}

The authors declare that they have no competing interests.

\section{Consent for publication}

Not applicable.

\section{Ethics approval and consent to participate}

The donor donating tissue gave written informed consent, and this study was approved by the Institutional Review Board at the Traditional Chinese Medicine of Changzhou Hospital.

\section{Author details}

${ }^{1}$ The Affiliated Hospital of Nanjing University of Chinese Medicine, Traditional Chinese Medicine of Changzhou Hospital, Changzhou, People's Republic of China. ${ }^{2}$ Nanjing University of Chinese Medicine, Nanjing, People's Republic of China. ${ }^{3}$ Jiangsu Province Hospital of TCM, Nanjing, People's Republic of China. ${ }^{4}$ Department of Oncology, the Affiliated Hospital of Nanjing University 
of Chinese Medicine, Jiangsu Province Hospital of TCM, Nanjing, People's Republic of China.

\section{Received: 11 February 2016 Accepted: 13 September 2016} Published online: 30 September 2016

\section{References}

1. Guo J, Miao Y, Xiao B, Huan R, Jiang Z, Meng D, Wang Y. Differentia expression of microRNA species in human gastric cancer versus non-tumorous tissues. J Gastroenterol Hepatol. 2009;24(4):652-7.

2. Jemal A, Bray F, Center MM, Ferlay J, Ward E, Forman D. Global cancer statistics. CA. 2011;61(2):69-90.

3. Hartgrink HH, Jansen EP, van Grieken NC, van de Velde CJ. Gastric cancer. Lancet. 2009;374(9688):477-90.

4. Ling $C Q$, Yue $X Q$, Ling $C$. Three advantages of using traditional Chinese medicine to prevent and treat tumor. J Integr Med. 2014;12(4):331-5.

5. Xiu LJ, Sun DZ, Jiao JP, Yan B, Qin ZF, Liu X, Wei PK, Yue XQ. Anticancer effects of traditional Chinese herbs with phlegm-eliminating properties An overview. J Ethnopharmacol. 2015;172:155-61.

6. Ling CQ, Wang LN, Wang Y, Zhang YH, Yin ZF, Wang M, Ling C. The roles of traditional Chinese medicine in gene therapy. J Integr Med. 2014;12(2):67-75.

7. Wang LN, Wang Y, Lu Y, Yin ZF, Zhang YH, Aslanidi GV, Srivastava A, Ling $C Q$, Ling C. Pristimerin enhances recombinant adeno-associated virus vector-mediated transgene expression in human cell lines in vitro and murine hepatocytes in vivo. J Integr Med. 2014;12(1):20-34.

8. Niland CN, Merry CR, Khalil AM. Emerging roles for long non-coding rnas in cancer and neurological disorders. Front Genet. 2012;3:25.

9. Mitra SA, Mitra AP, Triche TJ. A central role for long non-coding RNA in cancer. Front Genet. 2012;3:17.

10. Klecka J, Holubec L, Pesta M, Topolcan O, Hora M, Eret V, Finek J, ChottovaDvorakova M, Babjuk M, Novak K, et al. Differential display code 3 (DD3/ PCA3) in prostate cancer diagnosis. Anticancer Res. 2010;30(2):665-70.

11. Silva JM, Perez DS, Pritchett JR, Halling ML, Tang H, Smith DI. Identification of long stress-induced non-coding transcripts that have altered expression in cancer. Genomics. 2010;95(6):355-62.

12. Kogo R, Shimamura T, Mimori K, Kawahara K, Imoto S, Sudo T, Tanaka F, Shibata K, Suzuki A, Komune S, et al. Long noncoding RNA HOTAIR regulates polycomb-dependent chromatin modification and is associated with poor prognosis in colorectal cancers. Cancer Res. 2011;71(20):6320-6.

13. Gupta RA, Shah N, Wang KC, Kim J, Horlings HM, Wong DJ, Tsai MC, Hung T, Argani P, Rinn JL, et al. Long non-coding RNA HOTAIR reprograms chromatin state to promote cancer metastasis. Nature. 2010;464(7291):1071-6.

14. Ji P, Diederichs S, Wang W, Boing S, Metzger R, Schneider PM, Tidow N, Brandt B, Buerger H, Bulk E, et al. MALAT-1, a novel noncoding RNA, and thymosin beta4 predict metastasis and survival in early-stage non-small cell lung cancer. Oncogene. 2003;22(39):8031-41.

15. Lu B, Xu Y, Xu L, Cong X, Yin L, Li H, Peng J. Mechanism investigation of dioscin against CCl4-induced acute liver damage in mice. Environ Toxicol Pharmacol. 2012;34(2):127-35.

16. Cui $\mathrm{H}$, Onyango $\mathrm{P}$, Brandenburg S, Wu Y, Hsieh CL, Feinberg AP. Loss of imprinting in colorectal cancer linked to hypomethylation of H19 and IGF2. Cancer Res. 2002;62(22):6442-6.

17. Gao LL, Li FR, Jiao P, Yang MF, Zhou XJ, Si YH, Jiang WJ, Zheng TT. Paris chinensis dioscin induces G2/M cell cycle arrest and apoptosis in human gastric cancer SGC-7901 cells. World J Gastroenterol. 2011;17(39):4389-95.

18. Cai J, Liu M, Wang Z, Ju Y. Apoptosis induced by dioscin in Hela cells. Biol Pharm Bull. 2002;25(2):193-6.

19. Wang Z, Zhou J, Ju Y, Zhang H, Liu M, Li X. Effects of two saponins extracted from the polygonatum Zanlanscianense pamp on the human leukemia (HL-60) cells. Biol Pharm Bull. 2001;24(2):159-62.

20. Wang Y, Che CM, Chiu JF, He QY. Dioscin (saponin)-induced generation of reactive oxygen species through mitochondria dysfunction: a proteomicbased study. J Proteome Res. 2007;6(12):4703-10.

21. Lv L, Zheng L, Dong D, Xu L, Yin L, Xu Y, Qi Y, Han X, Peng J. Dioscin, a natural steroid saponin, induces apoptosis and DNA damage through reactive oxygen species: a potential new drug for treatment of glioblastoma multiforme. Food Chem Toxicol. 2013;59:657-69.

22. Yang F, Bi J, Xue X, Zheng L, Zhi K, Hua J, Fang G. Up-regulated long noncoding RNA H19 contributes to proliferation of gastric cancer cells. FEBS J. 2012;279(17):3159-65.
23. Matouk IJ, DeGroot N, Mezan S, Ayesh S, Abu-lail R, Hochberg A, Galun E. The H19 non-coding RNA is essential for human tumor growth. PLoS One. 2007;2(9), e845.

24. Tsang WP, Ng EK, Ng SS, Jin H, Yu J, Sung JJ, Kwok TT. Oncofetal H19derived miR-675 regulates tumor suppressor RB in human colorectal cancer. Carcinogenesis. 2010;31(3):350-8.

25. Wu Y, Zhang L, Wang Y, Li H, Ren X, Wei F, Yu W, Wang X, Zhang L, Yu J, et al. Long noncoding RNA HOTAIR involvement in cancer. Tumour Biol. 2014;35(10):9531-8.

26. Endo H, Shiroki T, Nakagawa T, Yokoyama M, Tamai K, Yamanami H, Fujiya T, Sato I, Yamaguchi K, Tanaka N, et al. Enhanced expression of long noncoding RNA HOTAIR is associated with the development of gastric cancer PLoS One. 2013;8(10), e77070.

27. Xu ZY, Yu QM, Du YA, Yang LT, Dong RZ, Huang L, Yu PF, Cheng XD. Knockdown of long non-coding RNA HOTAIR suppresses tumor invasion and reverses epithelial-mesenchymal transition in gastric cancer. Int J Biol Sci. 2013;9(6):587-97.

28. Niinuma T, Suzuki H, Nojima M, Nosho K, Yamamoto H, Takamaru H, Yamamoto E, Maruyama R, Nobuoka T, Miyazaki Y, et al. Upregulation of miR-196a and HOTAIR drive malignant character in gastrointestinal stromal tumors. Cancer Res. 2012;72(5):1126-36.

29. Tong Q, Qing Y, Wu Y, Hu X, Jiang L, Wu X. Dioscin inhibits colon tumor growth and tumor angiogenesis through regulating VEGFR2 and AKT/MAPK signaling pathways. Toxicol Appl Pharmacol. 2014;281(2):166-73.

30. Kim EA, Jang JH, Lee YH, Sung EG, Song IH, Kim JY, Kim S, Sohn HY, Lee TJ. Dioscin induces caspase-independent apoptosis through activation of apoptosis-inducing factor in breast cancer cells. Apoptosis. 2014;19(7):1165-75.

31. Hu M, Xu L, Yin L, Qi Y, Li H, Xu Y, Han X, Peng J, Wan X. Cytotoxicity of dioscin in human gastric carcinoma cells through death receptor and mitochondrial pathways. J Appl Toxicol. 2013;33(8):712-22.

\section{Submit your next manuscript to BioMed Central and we will help you at every step:}

- We accept pre-submission inquiries

- Our selector tool helps you to find the most relevant journal

- We provide round the clock customer support

- Convenient online submission

- Thorough peer review

- Inclusion in PubMed and all major indexing services

- Maximum visibility for your research

Submit your manuscript at www.biomedcentral.com/submit
C) Biomed Central 